\title{
The economic organization of decommissioning nuclear power plants - an institutional economic analysis with case studies in the US, UK, and Germany
}

\author{
Ben Wealer ${ }^{1,2}$ \\ ${ }^{1}$ Workgroup for Infrastructure Policy (WIP), Berlin Institute of Technology, \\ Straße des 17. Juni 135, 10623 Berlin, Germany \\ ${ }^{2}$ German Institute for Economic Research (DIW Berlin), Mohrenstraße 58, 10117 Berlin, Germany \\ Correspondence: Ben Wealer (bw@wip.tu-berlin.de)
}

Published: 10 November 2021

\begin{abstract}
The process of decommissioning nuclear power plants (NPP) is a multidisciplinary task that involves technical, regulatory, financial, and organizational activities. In order to fully decommission and subsequently release a reactor from regulatory control, a multitude of tasks need to be realized, i.e., defueling the reactor core, storing spent nuclear fuel, decontamination work, deconstructing conventional buildings, etc. Decommissioning is thus an intricate good that includes the supply of a variety of services, which must be produced upstream or offered in parallel.

This paper provides an economic analysis of different options of organizing (or: governing) the decommissioning process, so as to minimize the total costs for society, while of course respecting security standards set by the regulator. The costs of providing decommissioning result from the production and transaction costs. The former are largely determined by technical aspects and development of the decommissioning process, and the possibility of exploiting economies of scale and scope. Transaction costs, on the other hand, mainly result from coordination between the different tasks as well as the involved actors, often private and public actors with different target systems and equipped with different resources.

Transaction cost economics (TCE) is used to identify coordination areas and applied to formulate propositions on how nuclear utilities, decommissioning service suppliers, and waste management companies can establish vertical coordination. Transactions in the decommissioning process take place in a regulated environment and are governed, at least partially, by some public actors. In general, market governance is often assumed to be the most efficient governance structure, but in this context, our hypothesis is that institutional constraints, uncertainty, and factor specificity may call for other governance forms (Williamson, 1985). First analyses of the actors and the potential of the decommissioning market suggest an only slowly evolving market with only a few specialized companies and their subsidiaries able to provide technologically demanding services (Seidel and Wealer, 2015; Volk et al., 2019), while small and medium companies are confronted with high barriers to entry into the market (EC, 2018).

Nuclear countries have implemented quite different organizational models, varying from specific national decommissioning strategies implemented by a public agency to a relatively free choice of the strategy for plant operators (Wealer et al., 2019). In some countries, procurement laws have been put into place to create a competitive market. However, as the decommissioning market has evolved, challenges to the competitive ideal have arisen, i.e., market concentration and asymmetries of information. This oligopolistic structure combined with the increase in demand for decommissioning services gives rise to concerns regarding the functionality of the market. There are also key logistical issues that must be addressed, including supply chain bottlenecks and procurement strategies. A unified finding is that decommissioning is highly interlinked with nuclear waste management and is also the main source of uncertainty in terms of cost as well as the length of the decommissioning process, as
\end{abstract}


the missing disposal solutions for high-level radioactive waste render it impossible to release the nuclear power plants from regulatory control.

Kurzfassung. Der Prozess der Stilllegung von Kernkraftwerken (KKW) ist eine multidisziplinäre Aufgabe, die technische, regulatorische, finanzielle und organisatorische Maßnahmen beinhaltet. Um einen Reaktor vollständig stillzulegen und anschließend aus der behördlichen Kontrolle zu entlassen, muss eine Vielzahl von Aufgaben durchgeführt werden, z. B. die Entnahme der Brennelemente aus dem Reaktorkern, die Lagerung abgebrannter Brennelemente, Dekontaminationsarbeiten, der Rückbau konventioneller Gebäude etc. Die Stilllegung ist somit ein komplexes Projekt, das die Erbringung einer Vielzahl von Dienstleistungen umfasst, die im Vorfeld erbracht oder parallel angeboten werden müssen.

Dieser Beitrag liefert eine wirtschaftliche Analyse verschiedener Optionen für die Organisation des Stilllegungsprozesses, um die Gesamtkosten für die Gesellschaft zu minimieren, wobei natürlich die von der Aufsichtsbehörde festgelegten Sicherheitsstandards eingehalten werden müssen. Die Kosten der Stilllegung ergeben sich aus den Produktions- und den Transaktionskosten. Erstere werden weitgehend von technischen Aspekten und der Ausgestaltung des Stilllegungsprozesses sowie der Möglichkeit der Nutzung von Größen- und Verbundvorteilen bestimmt. Die Transaktionskosten hingegen ergeben sich hauptsächlich aus der Koordination der verschiedenen Aufgaben und der beteiligten Akteure, bei denen es sich häufig um private und öffentliche Akteure mit unterschiedlichen Zielsystemen und unterschiedlichen Ressourcen handelt.

Die Transaktionskostenökonomie wird eingesetzt, um Koordinationsbereiche zu identifizieren und Vorschläge zu machen, wie Kernkraftwerke, Anbieter von Stilllegungsdienstleistungen und Entsorgungsunternehmen eine vertikale Koordination realisieren können. Die Transaktionen im Stilllegungsprozess finden in einem regulierten Umfeld statt und werden zumindest teilweise von einigen öffentlichen Akteuren gesteuert. Im Allgemeinen wird davon ausgegangen, dass Marktbezug am effizientesten ist, aber in diesem Zusammenhang gehen wir davon aus, dass institutionelle Zwänge, Unsicherheit und Faktorspezifität andere Organisationsmodelle erforderlich machen könnten (Williamson, 1985). Erste Analysen der Akteure und des Potenzials des Stilllegungsmarktes deuten auf einen sich nur langsam entwickelnden Markt hin, auf dem nur wenige spezialisierte Unternehmen und ihre Tochtergesellschaften in der Lage sind, technologisch anspruchsvolle Dienstleistungen zu erbringen (Seidel und Wealer, 2015; Volk et al., 2019), während kleine und mittlere Unternehmen mit hohen Markteintrittsbarrieren konfrontiert sind (EC, 2018).

Die Länder, die Kernkraftwerke betreiben, haben ganz unterschiedliche Organisationsmodelle eingeführt, die von spezifischen nationalen Stilllegungsstrategien, die von einer öffentlichen Behörde umgesetzt werden, bis hin zu einer relativ freien Wahl der Strategie für die Betreiber reichen (Wealer et al., 2019). In einigen Ländern wurde die Auftragsvergabe gesetzlich geregelt, um einen Wettbewerbsmarkt zu schaffen. Mit der Entwicklung eines Stilllegungsmarktes haben sich jedoch Herausforderungen für das Wettbewerbsideal ergeben, namentlich Marktkonzentration und Informationsasymmetrien. Diese oligopolistische Struktur in Verbindung mit der steigenden Nachfrage nach Stilllegungsdienstleistungen gibt Anlass zu Bedenken hinsichtlich der Funktionsfähigkeit des Marktes. Es gibt auch wichtige logistische Fragen, die angegangen werden müssen, unter anderem Engpässe in der Lieferkette und Auftragsvergabestrategien. Generell lässt sich feststellen, dass die Stilllegung in hohem Maße mit der Entsorgung nuklearer Abfälle verknüpft ist und auch die Hauptquelle für Unsicherheit in Bezug auf die Kosten und die Dauer des Stilllegungsprozesses darstellt, da die fehlenden Entsorgungslösungen für hochradioaktive Abfälle es unmöglich machen, die Kernkraftwerke aus der behördlichen Kontrolle zu entlassen.

Financial support. This research has been supported by the Deutsche Forschungsgemeinschaft (grant no. Project number 423336886).

\section{References}

EC: Study on the Market for Decommissioning Nuclear Facilities in the European Union, European Commission - DirectorateGeneral for Energy, Brussels, 2018.
Seidel, J. P. and Wealer, B.: Rückbau von Kernkraftwerken in Deutschland. Analyse von Organisationsmodellen, Status Quo des Rückbaus, Marktbeobachtung und internationale Erfahrungen, TU Berlin, Berlin, 2015.

Volk, R., Hübner, F., Hünlich, T., and Schultmann, F.: The Future of Nuclear Decommissioning - A Worldwide Market Potential Study, Energ. Policy, 124, 226-261, https://doi.org/10.1016/j.enpol.2018.08.014, 2019.

Wealer, B., Seidel, J. P., and von Hirschhausen, C.: Decommissioning of Nuclear Power Plants and Storage of Nuclear Waste: Experiences from Germany, France, and the U.K., in: The Technolog- 
ical and Economic Future of Nuclear Power, edited by: Haas, R., Mez, L., and Ajanovic, A., Springer VS, Wiesbaden, 261-286, https://doi.org/10.1007/978-3-658-25987-7_12, 2019.
Williamson, O. E.: The Economic Institutions of Capitalism: Firms, Markets, Relational Contracting, Free Press, New York, 1985. 